\title{
THE NEMATOCYSTS OF EOLIDS
}

\author{
OTTO C. GLASER \\ Assistant Professor of Zoölogy, University of Michigan \\ ELEVEN FIGURES
}

CONTENTS

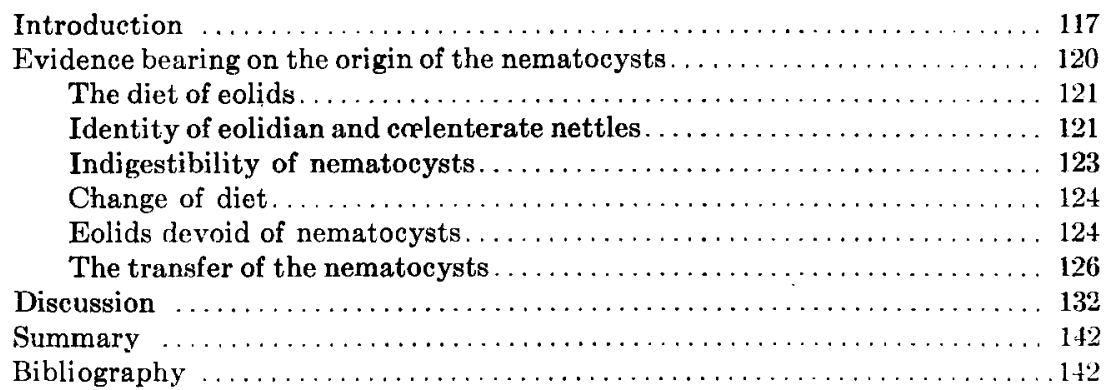

\section{INTRODUCTION}

The note on the nematocysts of nudibranch molluscs which I published in the Circular of the Johns Hopkins University in March, 1903, was the outcome of suggestions made by Professor Brooks, not only as to the possible origin of eolidian nettles, but as to the advisability of presenting at once the evidence at that time available. The necessity of teaching in summer schools during the only months when work on eolids is possible has caused the delays which have robbed me of the pleasure of offering my results prior to partial anticipation by others, and in time for Dr. Brooks to see them.

${ }^{1}$ From the Zoölogical Laboratory of the University of Michigan. 
In addition to the rhinophores (fig. 1), with their parallel rings, and the mobile foot-tentacles, sensitive to touch, eolids possess numerous dorsal appendages, or cerata. These structures, often banded distally, and tipped with blue, purple, grey, or white, occur in clusters symmetrically distributed on the sides of the body. When, as is frequently true, the cerata are very abundant, their distribution seems to be uniform; nevertheless each ceras belongs to a particular group that radiates from an enlargement on the side of the body. These swellings are regions of prolifer-

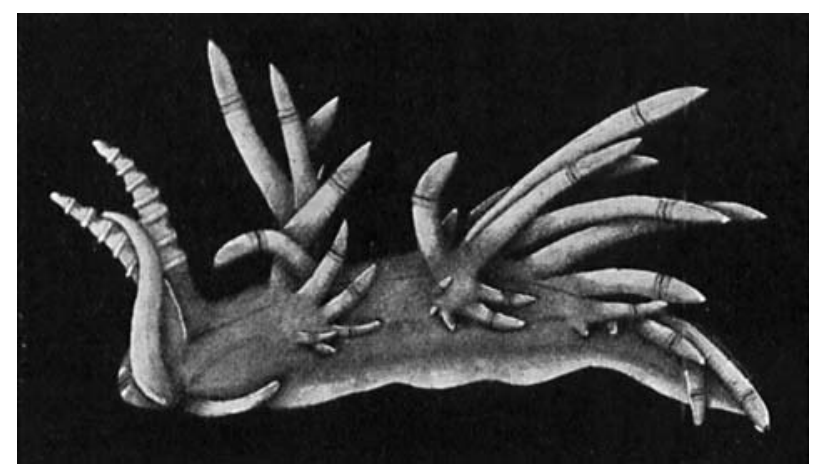

Fig. 1 Typical eolid, showing rhinophores with parallel ring-like swellings; foot-tentacles, and cerata of various sizes radiating in groups from lateral enlargements.

ation and from them arise new appendages in such manner that the oldest in each collection is nearest the sagittal axis of the animal.

A median section through such a ceras (fig. 2), shows an ectodermal covering $(E C T)$, indistinct in cell-boundaries, and rich in mucous glands. Inside this are bundles of longitudinal and circular muscles $\left(M U S C^{\prime}\right)$, enclosing a more or less capacious duct whose distal pore (CNDP), completes a passageway from the lumen of the liver to the outside. This duct, lined proximally with hepatic cells, then with ciliated epithelium, leads distally into a cnidophore filled partially or completely with cells or cysts containing nettles. The basal entrance into the cnidophore is guarded by a sphincter $(S P H)$. 
The morphology of the cerata is so thoroughly understood, that there is no need to add anything to the writings of Davenport ('93), Hecht ('96), or Krembzow ('02). The origin of the nematocysts, however, is still a subject for debate since many

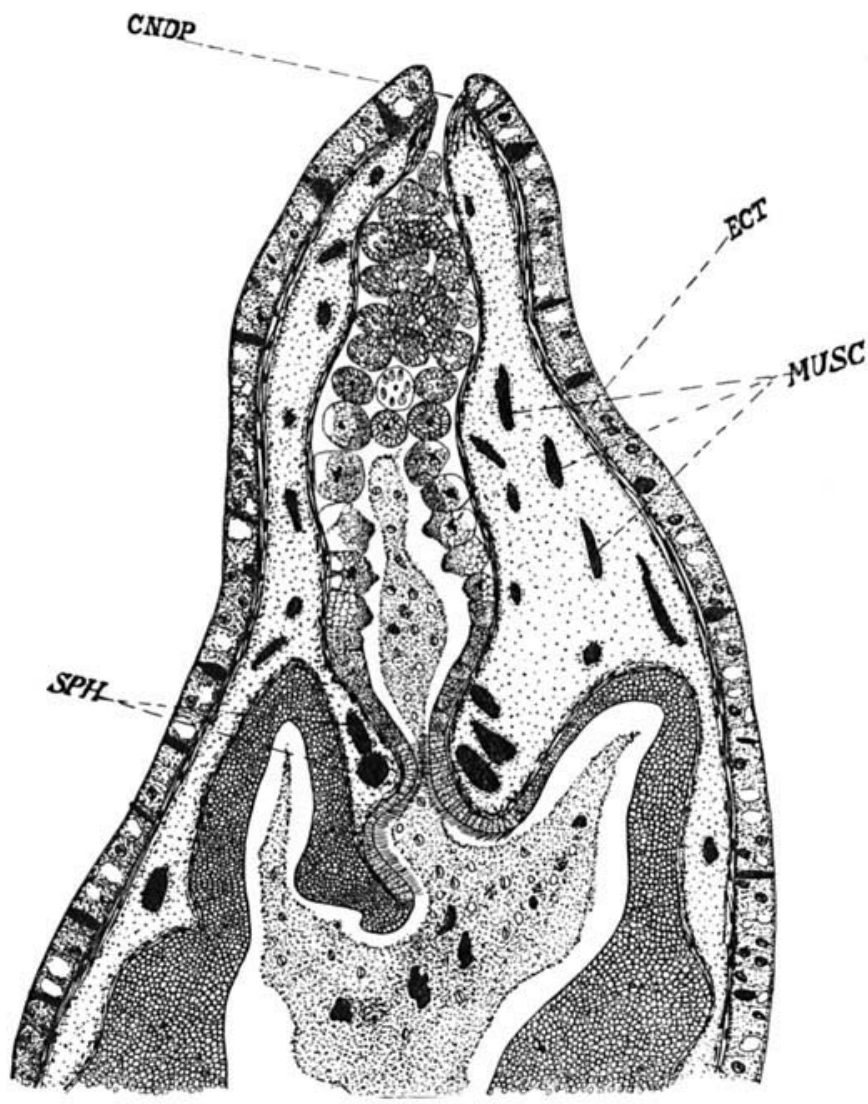

Fig. 2 Diagrammatic median longitudinal section through ceras showing complete cnidophoral system. CNDP., cnidopore; ECT., ectoderm; MUSC., longitudinal and circular muscles; SPH., sphincter.

biologists remain incredulous despite the published evidence. Grosvenor ('03) pointed out that this was the attitude assumed by some authorities toward T. Strethill Wright, who in 1858 read, before the Royal Physical Society of Edinburgh, a paper in which he attempted to show that the nematocysts of eolids are 
derived from their hydroid prey. According to Wright, the possibility of this had occurred previously to Huxley and to Gosse, the latter of whom suggested methods of experimentation. Wright's evidence failed to convince Alder who considered the extraneous origin of the nettles improbable. Bergh, too, in a paper, abstracted in the Microscopical Journal ('62), described the nematocysts of several additional genera and species and interpreted them as secretions of the cnidophore.

Bergh's failure to discuss Wright's work, led the latter to publish in the next volume of the same journal an abstract of his former paper, together with additional evidence which seemed to confirm the original contention. Grosvenor says: "Owing either to the absence of figures or the aforementioned improbability of the conclusions it contained, this abstract seems to have been overlooked as completely as the original paper." All observers, from 1861 to 1903 , failed to acquaint themselves with Wright's work, and assumed that the nematocysts were "manufactured" by the eolids in which they are found. Bergh himself, however, seems afterward to have entertained suspicions.

In the autumn of $1903 \mathrm{G}$. H. Grosvenor resurrected Wright's results, which, like all other writers, I too had overlooked, and on the basis of new experiments and histological observations gave an excellent account of the origin of the nematocysts. Recently Cuénot ('07), doubting both Grosvenor's statements and mine, re-investigated the subject, and now believes that the nettles are derived from cœlenterates. Cuénot's paper, however, contains fewer cytological details than the earlier one by Grosvenor.

\section{EVIDENCE BEARING ON THE ORIGIN OF THE NEMATOCYSTS}

One who maintains that the nematocysts of eolids are derived from their coelenterate prey, must be prepared to answer certain questions:

a. Do eolids feed on cœlenterates?

$b$. Are the nematocysts of eolids identical with those of their pres?

c. Are nematocysts indigestible? 
d. Can the nematocyst content of an eolid be altered by a change in diet?

$e$. Does a nematocyst-bearing species ever have individuals devoid of nettles?

$f$. Can the transfer of nematocysts from colenterates to the cnidophores of eolids be followed in detail?

\section{The diet of eolids}

The literature is full of testimony alleging the close association of eolids and cœlenterates. Moreover, eolids have frequently been observed while feeding on their colenterate neighbors. I have often seen them browsing on Tubularia crocea; on Eudendrium racemosum; and on actinians. Many species are so translucent that their food gives its color to the entire animal, and individuals which have fed on the pink heads of Eudendrium, or the somewhat paler ones of Tubularia, have the exact tints characteristic of these hydroids. Careful examination shows that the colors are due to undigested food in the alimentary canal and its diverticula.

\section{Identity of eolidian and colenterate nettles}

As Grosvenor says, "Those who quote the nematocysts of nudibranchs and coelenterates as a striking example of homoplasy or convergence, can scarcely be aware of the astonishing completeness of this assumed convergence." His assertion is supported by a considerable number of cases in which the isomorphism extends to the minutest details. Wright and Cuénot made similar observations. A number of equally striking instances have come to my notice, but I shall describe only two.

Among the sagartias attached in great numbers to oyster shells, at Beaufort, N. C., I found one eolid with nematocysts absolutely like those occurring in the tentacles of the actinian. The undischarged nettle of sagartia is a small rod in whose long axis lies a straight filament. Unexploded capsules answering to this 
description were found in the cnidophores of the eolid (fig. $3, A$ ). The complete identity of the two kinds was demonstrated by the discharged filaments, for these are characteristically barbed. Near its base (fig. 3, B), each thread has a large number of minute barbules directed toward the capsule. This region is followed by one with stouter barbs, and this in turn by one with small. The extreme tip of the thread is bare. Such a filament is sufficiently marked to make its recognition easy.

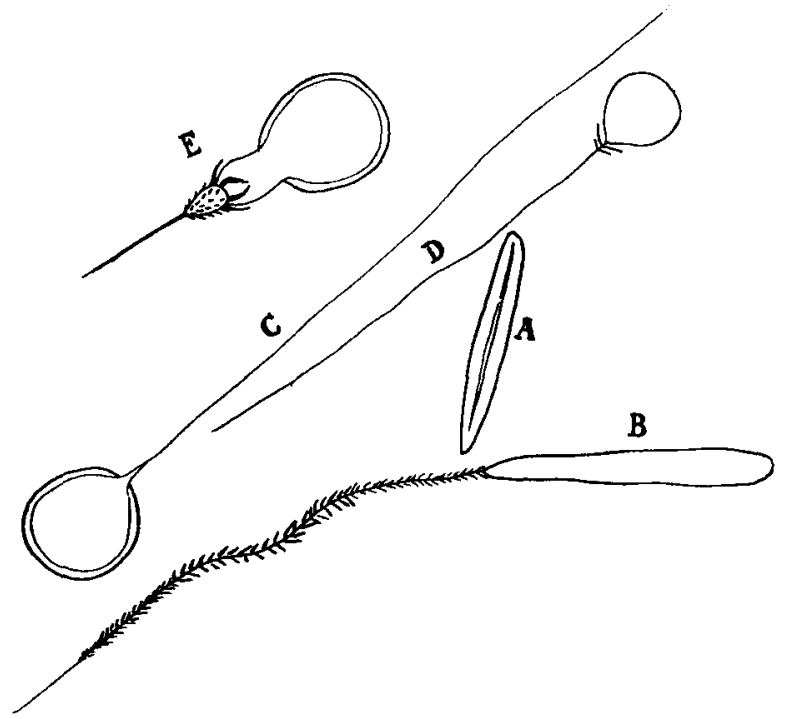

Fig. 3 A, B, nematocysts of Sagartia and of an eolid which preys on Sagartia; C, D, E, three types of tubularian nematocysts found in eolids which prey on Tubularia.

The most striking case which I have observed is the following: at Beaufort, also, another species of Eolis lives on Tubularia. An examination of the undischarged nematocysts of this tubularian divulges no great differences among them, but when exploded three kinds are easily recognizable. One (fig. $3, C$ ), has a long delicate thread completely devoid of barbules, and widening near the base where it is continuous with an almost spherical capsule. A second type (fig. $3, D$ ), less frequent, practically duplicates the first, except in two particulars: the capsule is considerably smaller, and the thread instead of widening at its base, is pro- 
vided with two pairs of barbs, of which the stouter is about three times the length of the other. The third type of nematocyst (fig. $3, E$ ) is the most common. In this the capsule is ovoid, and the discharged filament presents distinct regions. At the place where evagination occurs there is a bare projection crowned by four stout barbs with points directed toward the capsule. These four barbs originate in a crease between the barren mound and a considerably smaller distal swelling with many minute barbules pointing, like the large ones, toward the capsule. From the tip of this barbulated swelling the undifferentiated portion of the thread arises. The thread itself, however, is not without distinguishing characteristics; it is about twice the thickness of the threads of the first and second type, and about one-fifth as long; it is devoid of barbules and ends in an excessively fine point.

The cnidophores of eolids which prey on Tubularia contain nematocysts which in their discharged state agree point for point with one or the other of the three types found in the hydroid. That these three types represent developmental stages of only one kind of nettle seems unlikely, but even if they do, the argument from identity remains unchanged.

\section{Indigestibility of nematocysts}

If the source of eolidian nettles is cœlenterate food, it follows that the latter is not completely digestible. In a paper on the physiology of nematocysts ('09), I described certain methods of isolation whose success depends on the immunity of the capsules to at least two forms of digestion, peptic and putrefactive. In order to discover whether the nematocysts of eolids could be treated without destruction in the same manner as those of Hydra, Metridium, and Physalia, I subjected a large number of the cerata of Montagua to peptic digestion. The experiment gave a positive answer. Without immunity to digestive enzymes eolidian nettles could not be derived from cœlenterates, but the fact that they are indigestible is no argument in favor of derivation, since in the opposite case they would probably be equally resistant. 


\section{Change of diet}

Wright, Grosvenor and Cuenot, have studied the effect of an altered diet on the nematocyst content of eolids, and have demonstrated conclusively that the nettles vary with the food. Grosvenor's results particularly are so striking that there is scarcely need of insisting further on this point. I shall, however, add one case out of a number which I have collected.

In attempting to change the natural food of an eolid, one is confronted with an instance of strikingly specific diet, a condition suggested in nature. Montagua for instance, occurs only on Tubularia crocea, even when other hydroids are present. Indeed, late in the summer, when the colonies of $T$. crocea are degenerating or have almost disappeared, while Eudendrium is in fair condition, and Pennaria is flourishing, Montagua does not change its diet; instead it clings to its food supply as long as this endures, and in the end disappears to return only with the next crop of the hydroid.

This pronounced specificity interferes with attempts to replace the natural food of a species, but in a few instances I was able to substitute Aiptasia for Tubularia. The cerata of an eolid treated in this manner contained afterward the nematocysts characteristic of the anemone. A section through such a ceras is copied in fig. 4, and shows in addition to the great number of naturally captured nettles, those artificially introduced $(A-F)$.

\section{Eolids devoid of nematocysts}

Grosvenor has cited Calma glaucoides as an eolid normally devoid of nematocysts. According to Hecht, C. glaucoides feeds on the eggs and embryos of Cotta and other fish. Whereas this species has neither nettles nor cnidophores, Calma cavolinii, the only other member of the genus, feeds on hydroids and has typical cnidophores crowded with nematocysts.

These very suggestive facts can be duplicated within a given species. Thus in an earlier paper ('03), I mentioned an eolid which had been captured accidentally either before or during it. 


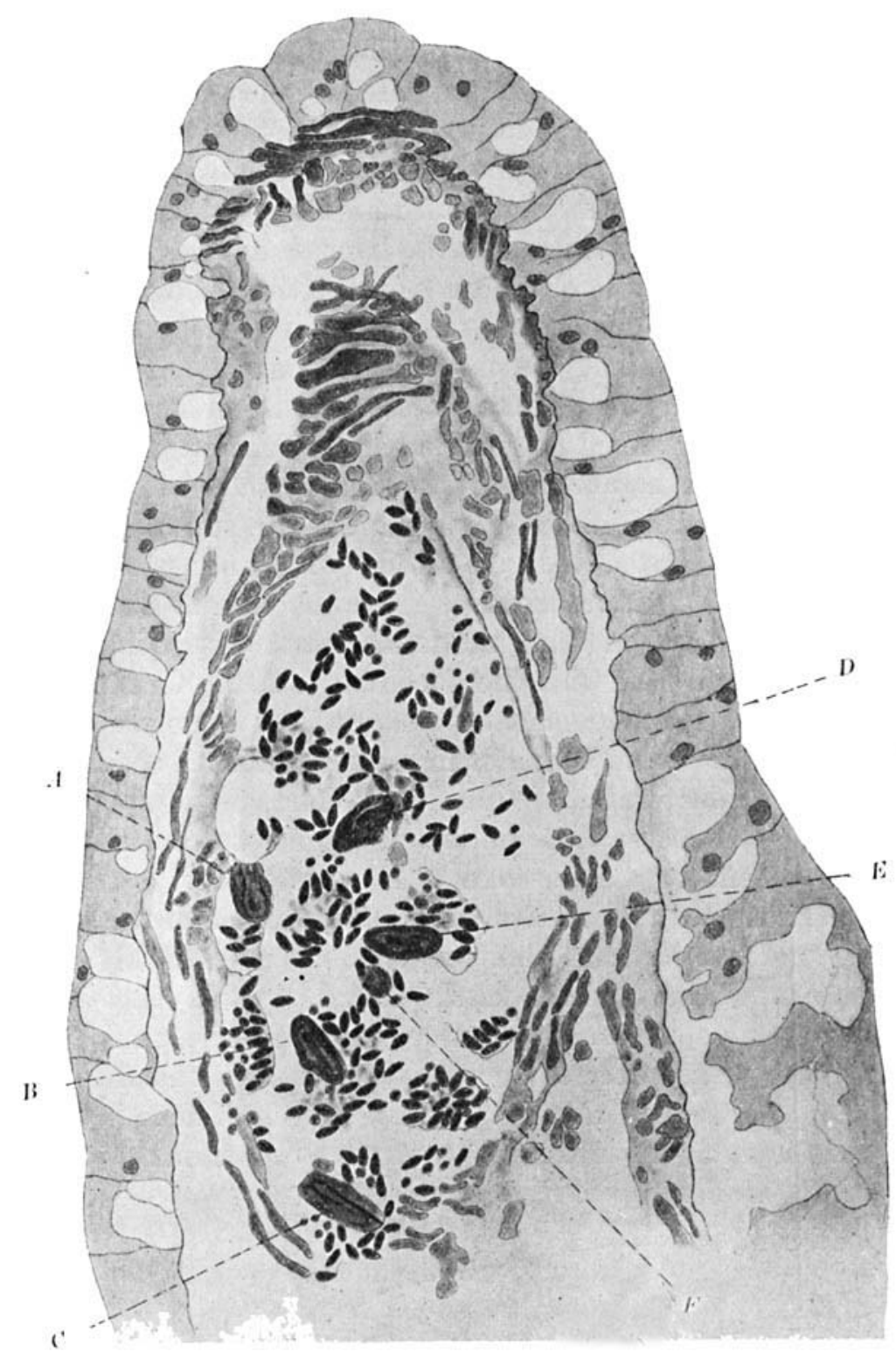

Fig. 4 Longitudinal section through the ceras of an eolid showing the normal nettles in great profusion, and at $A, B, C, D, E, F$, the artificially introduced nematocysts of Aiptasia. Drawn by Mr. Carl Kellner. 
metamorphosis, and had completed that process in an aquarium in which it lived for over two months. During the early part of this period, a few hydromedusæ were present, but these soon died out, and the eolid passed the greater portion of its captivity in the absence of cœlenterate food. Serial sections, upon careful examination, since repeated, revealed nothing that could be identified as a nematocyst, either in the liver or in the cnidophores.

Even under natural conditions cases of this kind may occur. Like Krembzow, I have found, on several occasions, eolids practically devoid of nematocysts, as well as barren cnidophores among many heavily charged. These facts are easily understood if the nematocysts are derived from cœlenterates, but on the contrary view they appear as abnormalities without known explanation.

The experiment of hatching and rearing the young in aquaria free of cœlenterates, would give an unequivocal answer could it be carried out. Many difficulties however, present themselves, most important of which are the fatal attacks of the infusorians inevitably introduced with the food and water. Cuénot ('07), nevertheless was able to make tests of a strictly analogous nature. By clipping the cerata and allowing regeneration to occur in the absence of cœlenterates, he produced eolids with appendages partly free of nettles. The failure to regenerate cerata entirely devoid of nematocysts was due to the presence of capsules in other portions of the digestive tract, in the lumen of the liver as well as of its diverticula, and engulfed even in the liver cells themselves. Many of these nettles found their way into the regenerating cnidophores, but even so, not in sufficient number to destroy the great contrast between the restored and the amputated appendages. This slight uncertainty in Cuénot's results could be eliminated entirely by starving the animals for four or five days before operating.

\section{The transfer of nemat.systs}

Cuénot has said that the best evidence of the derivation of solidian nettles is their history. This has been most carefully worked out by Grosvenor, and certain points in it have been 
touched upon by Cuénot. In what follows, Grosvenor's account is substantiated in all important respects.

What happens during artificial digestion unquestionably occurs in the alimentary canal of an eolid. The tissues of the food coelenterate are dissolved and the nematocysts remain in great quantities free in the lumen of the tube. Many of them are voided with the fæces, others find their way into the cnidophores.

The passage from the digestive tract proper to the cnidophore is through the ciliated canal. Even were there no direct observa-

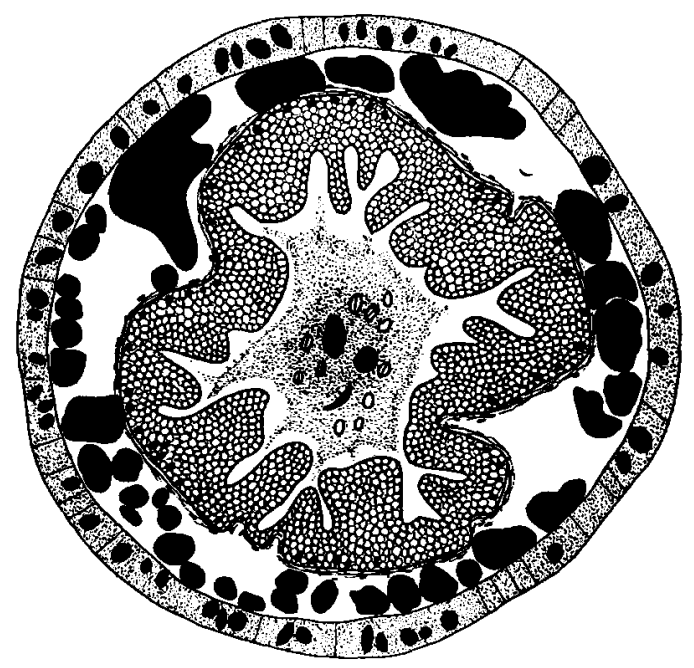

Fig. 5 Transverse section through the base of a ceras showing within the lumen of the liver diverticulum, certain uninterpretable fragments; a considerable number of undischarged nematocysts, and one crescentic diatom.

tions such as those of Hancock and Embleton ('46), Trinchese ('77-'81), and Grosvenor ('03), the occurrence of the same kinds in both cavities which the canal connects would suggest the derivation of the one group of nettles from the other. More suggestive still is the presence of "foreign" bodics in the cnidophore, a fact noted by Hecht, by Hancock and Embleton, and by Grosvenor. I have found uninterpretable fragments of tissue, bodies not tissue-like, and diatoms, in the liver diverticula and in the cnidophores. The ciliated canal apparently has no power to distinguish 
other indigestible bodies from nematocysts, but this inability to select is not shared by the cnidophages, for so far as I know, these ingest only nematocysts.

The cnidophages are derived from a zone of "embryonic" cells, located just distally to the ciliated canal. Fig. 6, a drawing of the proximal portion of a longitudinal section which happened not to strike the canal, shows the embryonic zone $(E M B . Z$.). Its cells have either no boundaries or incomplete ones; the nuclei are large and contain coarse chromatin granules; and the cytoplasm is undifferentiated. From this region of proliferation the oldest cells

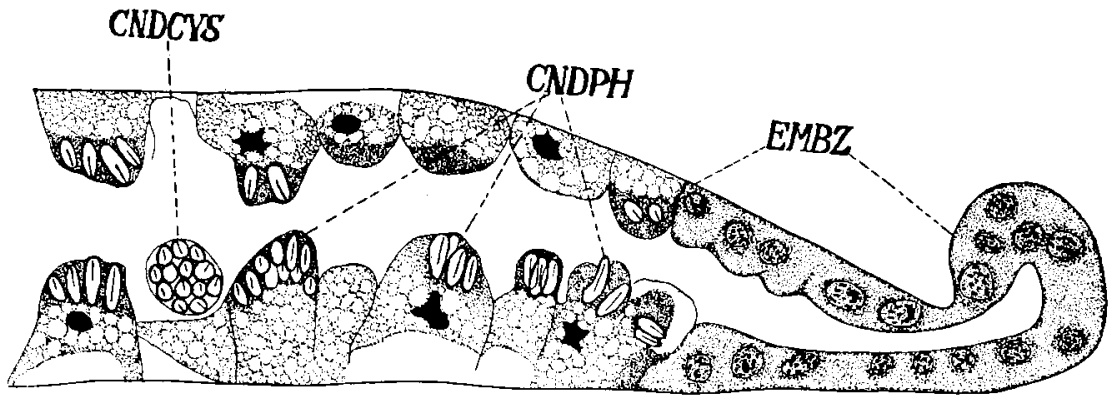

Fig. 6 Median longitudinal section through ceras; EMBZ., embryonic zone; CNDPH., enidophages; CNDCYS., enidocysts.

are pushed upward and enter the zone of enidophages (CNDPH.) where, after ingesting a number of nettles inversely variable with the size of the engulfed capsules, they become converted into cnidocysts (CNDCYS.).

No single description of the cnidophore would prove satisfactory since the various zones that compose it present phases which depend in part on the age of the appendage, in part on the number of nematocysts ingested. In cerata in which "feeding" is actively going on, or in which it might go on, certain cells show evidence of pseudopodial activity. In the transverse section, fig. 7, the lumen of the cnidophore is traversed and rendered labyrinthine basally, by projections from its bounding cells. Processes from several cells may fuse into larger bridges with, at 
times, branch connections to other cells. Though visible only in sections, the projections suggest activity, as if they had been fixed in the act of moving, or flowing. It is interesting that cnidophores well-stocked, do not contain these labyrinths. Apparently if the "fishing" results in a "catch," the cells withdraw their pseudopods.

Not all the cells produced by the embryonic zone become cnidophages. In addition to these, certain interstitial cells are formed

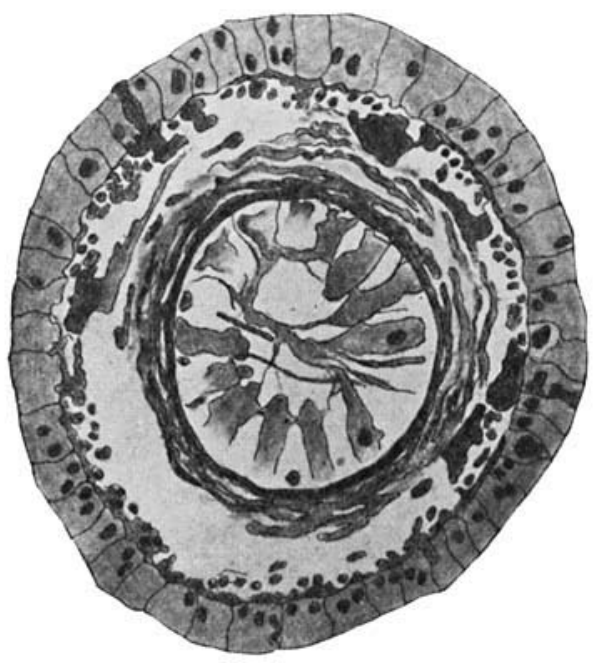

Fig. 7 Transverse section through a ceras in which the lumen is made labyrinthine by pseudopodia that project inwards from the bounding enidophages. Drawn by Mr. Carl Kellner.

whose fate is quite different. Fig. 8 illustrates part of a longitudinal section through basal cnidophages. The cells have ingested no nematocysts, but those which were about to, differ distinctly from the prospective interstitial cells. The latter are very narrow, have near their bases small densely staining undifferentiated nuclei, and have cytoplasm, which, wherever visible, resembles that found in the embryonic cells. Near the lumen of the cnidophore the interstitial cells have no membranous boundaries, although elsewhere they are definitely delimited. 
The prospective cnidophages undergo striking changes which emphasize still more the disparity in size between them and the interstitial cells. The young cnidophage enlarges, partly by the development of great vacuoles in the cytoplasm, (fig. 8), and partly because the cell contents withdraw from all except certain portions of their boundary, remaining connected with it only here and there by strands.

When the differentiation of the cnidophage is complete, it presents the appearance shown in fig. 9. Each cell has a receptive eminence in which the cytoplasm remains naked and in the

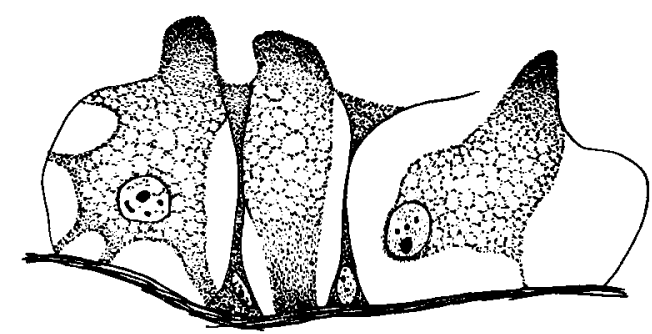

Fig. 8 Showing young enidophages with blunt pseudopodia. Also interstitial cells.

embryonic condition. From this point pseudopodia may be sent out, but in appendages in which ingestion has taken place, only short, blunt processes are found.

After the cnidophage has ingested its fill of nettles, degenerative metamorphosis sets in. This process is characterized chiefly by retrograde changes in the nucleus, which gradually looses all visible differentiation, and becomes irregularly lobed or stellate (fig. 6). As the finished cnidocyst shows no histological details other than the nematocysts and their enclosing membrane, the inference that nucleus and cytoplasm both degenerate completely seems well founded.

The complete history of the enidocyst remains in doubt. Grosvenor was not able to determine with certainty where the bounding membrane comes from, nor have my own efforts to 
solve the problem met with better success. A suggestion is all that I can offer. The wall of the cyst is tough, and has considerable thickness. It is apparently formed during the period when the cnidophage is degenerating. Under the circumstances it is not unlikely that this cell has nothing whatever to do with the formation of the cyst, but that the membrane in question is traceable to other cells. Grosvenor indeed suggested that the interstitial cells might aid in the secretion of the cyst; to me it seems equally plausible to assume that these cells alone are responsible. The best evidence which supports this view is fig. 10, in which are

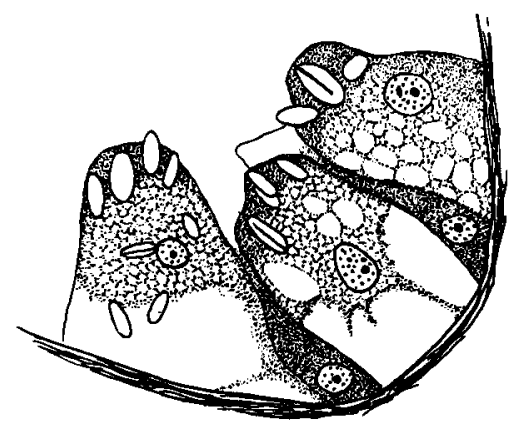

Fig. 9 Ingesting cnidophages showing differentiation and shrinkage from cell membranes. Also interstitial cells.

shown degenerating cnidophages, enclosed within compartments formed by interstitial cells which themselves have lost practically all of their original characteristics. As the figure illustrates they are reduced to mere membranes. Since each nettle-sac is complete, and in the ripe state capable of isolation from its fullows we must suppose on this view of the matter that the interstitial cell which lies between two or even three cnidophages contributes an independent portion to as many cnidocysts.

However they originate, the cnidocysts in their finished form are mere bags, thin-walled and transparent, filled with undischarge: nettles. The cysts may lie free in the lumen of the cnidophore, or loosely attached to its walls. In either case they are easily extruded through the enidophore by contractions of the cnidophoral musculature. 


\section{DISCUSSION}

While the demonstrated identity of eolidian and coelenterate nettles is clearly not due to homoplasy, the actual occurrences are not so simply disposed of. Instinctively one wonders how such complex interrelationships between two totally distinct sets of organisms could have come about, and to what extent the pro-

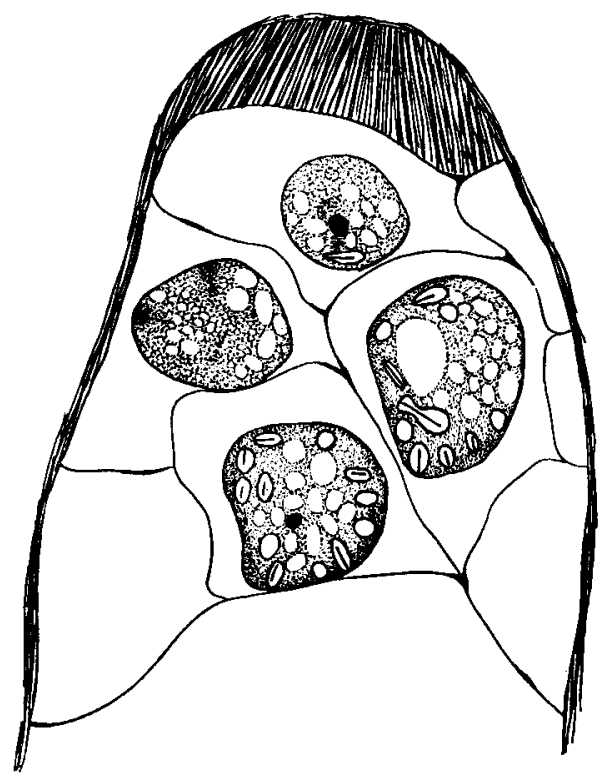

Fig. 10 Tangential section through the cnidophore showing young cnidocysts enclosed in spaces limited by degenerating interstitial cells.

cesses described may be said to be adaptivt. Before attempting to deal with the questions that arise, it will be well to summarize briefly what can be easily understood if the collected evidence is valid.

If the accounts of Wright, Grosvenor, Cuenot and myself, are to be trusted, it is easy to see why the nematocysts should be found inside of entodermal cells and their derivatives; it is easy 
also to understand why, as has been pointed out by Krembzow, the nucleus of the cnidophage takes no part whatever in the "manufacture" of the nematocysts; further the occurrence of individuals and of cerata devoid of nettles is readily explicable; and finally the identity of eolidian and cœlenterate nettles is no longer a case of convergence that exceeds the probabilities of homoplastic evolution. However, some things remain to be explained.

The first requisite for the development of these remarkable relations, is that eolids shall be immune to the nettling organs of coelenterates. Since nudibranchs are animals of unusual delicacy and apparently without protection, the freedom with which they crawl over hydroids and actinians, and browse upon their heavily charged tentacles, is intelligible only on the assumption that the dangers in the midst of which they live do not apply to them. It is not without interest to inquire how this can be.

The thought that most naturally comes to one is that in the course of time immunity has developed either by the elimination of individuals most prone to succumb to bombardmentfrom nematocysts, or that in each generation the individuals, by being constantly under fire, gradually become indifferent to the punctures and stings, and finally fail entirely to react to stimuli to which the uninitiated respond by lively movements, and possibly by sensations of pain. This reasoning, however, rests on the assumption not only that eolids are vulnerable, but that they are under fire, and both premises require qualification.

That eolids are sensitive to the bombardment of nematocysts can be shown by transferring an animal which normally lives on Tubularia to the dise of a large Aiptasia. If the animal is not swallowed, it may fall off and reach the bottom of the dish in a perfectly rigid paralytic state. Occasionally spasmodic and angular movements may be observed, but recovery is rare as the animal usually dies despite many precautions.

If the discrepancy in size be reversed, so that the eolid is considerably larger than the Aiptasia, the latter seems to affect to a marked degree only the highly sensitive foot-tentacles, and the eolid under certain circumstances may devour the actinian. The attack is made at the base, and as the anemone immediately re- 
tracts its disc when assaulted, it is devoured in its least dangerous state. The outcome of the two experiments is thus very different.

It follows from this that even an absolute immunity to the nematocysts of one cœlenterate does not insure immunity against those of another. The absolute immunity itself, however, does not exist. It has been said by several writers that eolids showing evidence of having been punctured either from without or within by the sort of nettles in which they normally traffic are unknown. Fig. 11 represents a cross section through a ceras taken from an

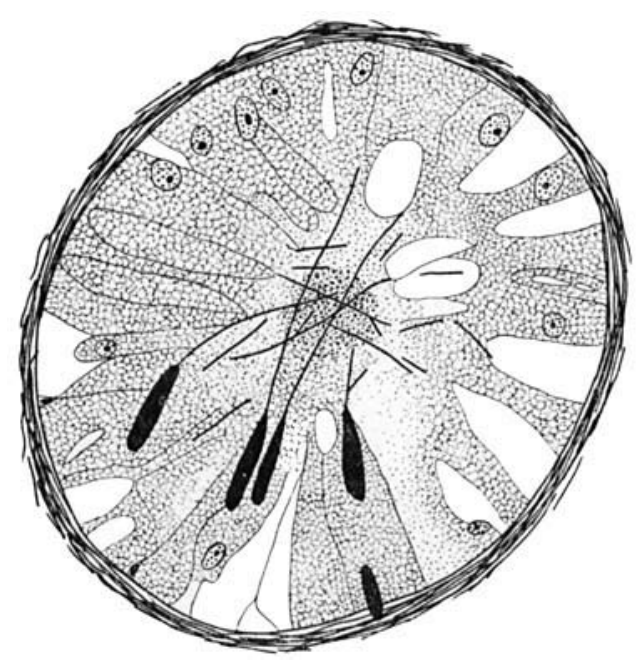

Fig. 11 Cross section through the base of a cnidophore in which intra-ceratal explosions have taken place.

eolid feeding normally on Aiptasia. The particular section is by no means representative, and gives a very inadequate idea of the number of discharges which has occurred in this appendage. My reason for choosing it is the ease with which the individual filaments can be traced to their capsules. Other sections contains inextricable snarls of threads.

Immunity, therefore, is relative and depends on several interesting details. It is not unlikely that phyletic as well as individual acclimatization plays a rôle; more important, however, are the reactions of cœlenterates to eolids, and most important the nema- 
tocysts themselves. When touched and particularly when about to be cropped, the tentacles of a hydroid or of an actinian contract, and consequently fewer nematocysts are likely to discharge than if the tentacle remained expanded. More to the point even than this is the fact that when tentacles are cut off quickly, no discharges, or only few occur. It follows, then, that eolids are not under a heavy fire to begin with.

But such fire as they are under does not of necessity reach them, for, aside from the protection offered by the mucus which they secrete, the bodies of eolids are not the sort to be easily punctured by nettling threads. Certain experiments performed while studying the physiology of nematocysts ('09) show that a soft surface is apt to ward off the filament, and further that penetration is most easily effected when the thread is under its maximum speed at the beginning of the explosion. In order that a surface may be broken in upon, it must be very close to the mouth of the discharging nettle. Furthermore, Toppe ('09) has shown by extremely careful and interesting observations that the most common type of hydroid nematocyst is especially adapted for puncturing hard, chitinous surfaces and not soft indentible ones.

That discharge of the nematocysts after ingestion does not take place, my own observations have shown to be untrue, nevertheless such explosions are rare. In the paper on the physiology of nematocysts ('09) it was shown that the discharge of the filament is really an explosion traceable to a rise in the internal pressure of the capsule. As this rise results normally from osmosis and as the fluids in the digestive tract of eolids are probably more concentrated than those inside the nematocysts, one can easily understand why explosions within the cerata should be rare enough to have hitherto escaped detection.

Finally, it is not unlikely that immunity in the narrower sense renders ineffective such penetrations as may occur. The evidence of a "Reizgift" postulated to explain the irritations set up by nematocysts, does not appear to me as yet quite conclusive ('09). On the other hand, the evidence that there is present in nettles another poison, the hypnotoxin, responsible for the paralysis of punctured animals, seems well grounded. It is quite possible 
that there existsin eolids an anti-body capable of neutralizing hypnotoxin, provided this substance is not introduced in too large quantities, or in a variety to which the anti-body is not adapted. If this sort of immunity exists, then the total "immunity" of an eolid to a particular type of nematocyst is due in part to the various factors which prevent the mollusc from being punctured; in part to acclimatization, phyletic or otherwise, to the mechanical effects of such punctures as are made; and finally to the neutralization of the small quantities of hypnotoxin introduced.

With the demonstration that immunity exists, but is relative and dependent on several distinct factors, the way is paved for a consideration of the origin of the nematocyst-storing habit.

The indigestibility of the nettles renders their elimination necessary. One way in which this is accomplished is by voidance with the fæces; another by voidance through the cnidopores. Why this second method should have developed is difficult to determine. According to Hecht ('96), Calma glaucoides is a typical eolid except in two respects; it has neither cnidophorc s nor nematocysts. Calma cavolinii, the only other member of the genus has cnidophores filled with nettles. As C. glaucoides in all probability did not branch off from the common eolid stock before the introduction of nettles, and as its habit of fetding upon the eggs and embryos of shore fish, such as Cotta, is, with equal probability secondary, it seems likely that the abandonment of the nematocyst habit is quichly followed by degeneration of the accessory organs of elimination. If this be true, one may infer that the presence of nematocysts influences the production of cnidophores, much as an insect sting may bring on, in a plant, the formation of galls.

I do not know what it is in nematocysts that renders their prompt removal from the digestive tract proper, desirable, nor whether the immediate end, whatever it be, is accomplished by the means employed. That elimination, or at least storage, is somehow useful, while not absolutely provea, is certainly probable, for the idea that it is profitless or harmful is difficult to harmonize with the complexity of the structures and processes involved. It must be borne in mind that a ciliated canal makes 
possible the easy passage of nematocysts from the digestive tract to the cnidophores; that specially adapted cnidophages store the nettles, and become converted, with the aid of interstitial cells, into cnidocysts; that these step out of line and are forced by means of a special musculature out of the cnidopore; and that there is a zone of "embryonic" tissue which furnishes a supply of cells for all the purposes of the cnidophore. In addition to elimination there are other ways in which the overloading of the cerata is prevented, for new appendages are constantly forming, and by autotomy, the largest and presumably best stocked cnidophores are frequently cast upon the slightest stimulation. Even in the absence of assignable specific reasons for the voidance of nettles it seems reasonable, in face of these facts to assume that the processes now known to occur are useful, and that elimination of nematocysts is the primary function of the cnidophore proper.

Grosvenor has given a possible history of this function and of the system of organs that carry it on. "In molluscs," he writes, "other than the cladohepatic Nudibranchs, the food is digested in the stomach, where absorption takes place . . . In Tritonia, therefore, the anus suffices for the passage of nematocysts out of the body. But in the Cladohepatica, part of the food is digested in the gastric gland, quite fresh pieces of hydroid being found in the ducts and ceratal diverticula of a recently fed Æolid.

How Dotonids which habitually feed on hydroids and have no aperatures in their cerata, get rid of the nematocysts, I cannot say; perhaps by throwing off their cerata, which as is well known they do with great ease. When an aperture for the extrusion of nematocysts had once been acquired, it would be obviously advantageous that the distal end of the "hepatic diverticulum" should be modified to form a cnidosac where the nematocysts might be stored." With this attempt at phylogenetic explanation, and the reasons cited to support it, I agree with one exception: to me it seems more probable that the "cnidosacs" as well as the habit of storing nettles are both older than the cnidopore from which extrusion takes place, and furthermore, that primitively, eolids probably cast off their excess nettles by autotomizing the cerata.

As a mechanism for voiding nematocysts, the enidophoral 
system is clearly fit. This however, does not tell us why elimination should take place, nor whether either this or the complicated machinery to secure it are more than compromise responses to the biological problem, whatever it be, that lies back of both. As long as the nematocysts were considered part of the organic make-up of eolids, a sufficient reason for their presence and behavior was found in their supposed utility; nor is the case necessarily altered by the demonstration that the nettles are visitors rather than natives in the bodies of these molluses. There are many details also which seem to add force to the argument from utility. It is a fact that the nematocysts of eolids explode on coming into contact with sea water or a medium more dilute. It is natural to infer that they are neither more nor less effective when extruded from a Montagua, than they would have been had they exploded in the mother tissues of the Tubularia that made them. It is likewise true that the explosion of these borrowed nettles is accompanied by sensations of pain if allowed to take place on a sensitive part of the body, between the fingers or on the tip of the tongue. Moreover eolids behave exactly as though a high degree of utility attached to the nettling organs. When stimulated, thermally or mechanically the nematocysts are extruded, and explode in great numbers. Grosvenor remarks:

"No one can have witnessed the reaction of an Aeolid to various stimuli . . without being convinced that the cerata are used as a means of defence. The body is contracted, the head being often nearly telescoped into the trunk while the cerata are erected and waved about, especially in the direction of the foreign body, and are often considerably extended.

Under these circumstances Grosvenor nevertheless did not witness the actual extrusion of nematocysts. Cuénot ('07), in discussing the same subject, writes:

"Lorsqu'on touche un Eolidien avec une baguette de verre, il prend aussitôt une attitude particulière; les papilles s'érigent, s'allongent et se tournent autant que possible vers le point lésé, comme si elles s'orientaient pour cribler l'ennemi de nématocystes; mais en réalité, comme le dit très justement Grosvenor, il y a très peu ou même pas du tout de 
nématocystes rejetés au dehors par la contraction des sacs. Cette attitude est donc purement émotive, et n'a pas d'effet défensif direct. Ce n'est que lorsqu'on tracasse violemment l'animal, ou mieux encore lorsque les papilles sont arrachées et comprimées, qu'il sort des sacs une masse de cellules nématophages et de nématocystes, qui explosent aussitôt. Il y a de très bonnes raisons, tirées du mode de fonctionnement des nématocystes, pour croire que cette explosion non dirigée ne peut avoir qu'un effet insignifiant . . . ; mais laissons cela et essayons des expériences."

In combats with its own kind it is not surprising that the dorsal appendages should be attacked, for not only are eolids "immune" to the nematocysts of the cerata, but these on stimulation are erected and project like the quills of a porcupine. The enemy comes unavoidably into contact with them. It is surprising, however, to witness exactly the same thing when a blennie meets an eolid. If the blennie is hungry it behaves in a seemingly pugnacious manner, darts at the eolid, seizes a mouth full of cerata, and pulls and twists them off as though they were tid-bits. As the blennie is one of the commonest denizens of regions inhabited by eolids we have here one instance at least, in which the defensive value of the nematocysts can be discounted.

Many experiments with Fundulus heteroclitus were made. In general this fish, in the first trial of an experiment will take an eolid, but almost instantly regurgitates the captive. Contrary to my earlier statement ('06), a second or even third trial may be made, depending on the degree of hunger, and if the Fundulus is very hungry, the eolid may finally be swallowed permanently. As the cerata are cast during these successive captures and regurgitations, it might be that the final retention is due to the loss of the nematocysts which at first rendered the eolid disagreeable.

Further experimentation shows that this view is untenable, for if eolids completely devoid of cerata, or forms naturally without nettles are used, a fundulus will repeat all the performances which it goes through when dealing with a normal individual bearing nematocysts. Leaving aside altogether the nettleless nudibranchs, the eolids employed in these experiments were not 
so seriously crushed during the trials that cost them their cerata, that the behavior of the fish could be due to nematocysts in other parts of the animal, so that obviously unpalatability to certain fish is a common property of nudibranchs, and by no means limited to the nettle-bearing species or individuals.

If these results, which are in complete harmony with those of Cuénot, are surprising, this is largely due to a common misapprehension as to the nature and significance of nematocysts. Whenever the word nematocyst is employed, it not unnaturally calls to mind the stinging artillery of a Discomedusa, or of a Portuguese man-of-war. Such armament is quite misleading, for its tremendous effects are by no means typical. Indeed the forms from which nudibranchs derive their nematocysts are themselves subject to attacks from the same fish which under certain circumstances will devour an eolid, and if the nettles of Eudendrium and of Tubularia do not protect them against browsing blennies, pinfish, and minnows, it is not to be expected that the same nettles transferred to another animal will gain in effectiveness.

In addition, the observations of Toppe ('09) suggest an important clew. Apparently the structural specialization among nematocysts is accompanied by specialization of function; for while some kinds serve as nettles, others are prehensile organs, and have nothing whatever to do with the infliction of wounds. These facts are very significant, for, aside from correcting a misconception widely spread, as to nematocysts in general, we now know definitely how the various kinds function and how beautifully each is adapted to certain specific ends. The adaptiveness of these structures is not in themselves, but comes about as the result of the habits of the animals producing them. It would be surprising indeed if a nematocyst, adapted to curl round the chitinous hairs of a copepod should be protective when exploding in the mouth of Fundulus.

Toppe's results suggest further that defense is not the original function of nematocysts, but that they are primarily organs of prehension for the purpose of entangling prey. From this standpoint it appears that the nettling function proper is secondary, 
and that in certain highly specialized Cnidaria, nematocysts subserving the secondary function have replaced the more primitive prehensile organs. As eolids feed on cœlenterates provided with large numbers of prehensile nematocysts, the observed inadequacy of the protection afforded is neither more nor less than one might expect.

On the basis of experiments similar to those I have presented in brief, Cuénot has concluded that the defensive value of eolidian nematocystsis slight. This inference, which the behavior of various fish makes valid receives additional support from the observations of Toppe and the conclusions to be drawn from them. It would be a mistake however to postulate complete inadequacy, for unquestionably the presence of nematocysts of all kinds in the cnidophores gives the cerata certain gustatorial peculiarities, which otherwise they would lack. When crushed on the tip of the tongue the sensation produced by a ceras is not unlike that of Tabasco Sauce. If this is added to the peculiarity, whatever it be, that renders nudibranchs in general distasteful to fish, we may conclude that a slight degree of defensive value attaches to the borrowed nettles.

According to Garstang's view ('88), shared by Grosvenor, the bright colors of the cerata serve "to direct the experimental attacks of young and inexperienced enemies to the non-vital papillæ, and away from the vital and inconspicuously colored parts of the body." The habit of responding to stimulation by erection, insures that the cerata shall bear the brunt of any attack whatever the experience of the enemy. As autotomy takes place with the greatest ease, it often happens during an encounter, that an eolid is obscured by a cloud of unattached brightly colored appendages, which, since their owner resembles the background, are certain to catch the eye of the enemy. Granted that the cerata are at least as distasteful as the body of the eolid; that in addition the presence of certain nematocysts adds even slightly to the disagreeable qualities, and one has in hand perhaps one of the minor factors in the persistance of the nematocyst-habit. 


\section{SUMMARY}

The nematocysts of eolids are derived from cœlenterates, and are not to be looked upon as an instance of homoplastic evolution. Their defensive value is slight, partly because nudibranchs are distasteful to their enemies even in the absence of nettles, and partly because many of the ingested nematocysts are adapted to meet exigencies in the lives of coelenterates which do not arise in those of eolids. A reason other than utility must therefore be discovered in order to explain the origin of the nematocyststoring habit.

\section{BIBLIOGRAPHY}

BERGH, R. 1862 On the existence of urticating filaments in the Mollusca. Abstract. Microscopical Journal N. S. vol. 2.

Cuénot, L. 1907 L'origine des nématocystes des Eolidiens. Arch. de Zool. Exp., 4e Série, T. 6.

Davenport, C. B. 1893 Development of cerata in Aolis. Bull. Mus. Comp. Zoöl., v, 22.

Garstang, W. 1888 . Opisthobranchiate Mollusca of Plymouth. Journ. M. B. A., N. S., v, 1.

Glaser, O. C. 1903 The nematocysts of nudibranch molluses. J. H. U. Circular, $\mathrm{v}, 22$.

Graser, O. C. 1906 The nematocysts of Eolis. Science, N. S. v, 23.

Glaser and Sparrow. 1909 The physiology of nematocysts. Journ. Exp. Zoöl., v, 6.

Grosvenor, G. H. 1903 On the nematocysts of Æolids. Proc. Royal Soc., v, 22.

Hancock And Embleton. 1846 Anatomy of Eolis. Ann. and Mag. of Nat. Hist., v, 15.

Неснт, H. 1896 Introduction á l'étude des nudibranches. Lille.

Krembzow, E. 1902 Ueber den Bau und die Entwickelung der Rückenanhänge bei Aeolidiern. Arch. f. Mik. Anat., ete., v, 59.

Toppe. 1909 Ueber die Wirkungsweise der Nesselkapseln von Hydra. Zool. Anz., Bd. 23.

Trinchese, S. 1877, 1881 Aolididæ e famiglie affine nel porto di Genova. i, Bologna, 1877-79; ii, Roma, 1881.

Wright, T. Strethild. 1858, 1861 On the cnidae or thread-cells of the Eolidæ. Proc. Royal Phys. Soc. Edinburgh, Sessions 1858-59: 1859-60; 1860-61.

Wroght, T. Strethili. 1863 On the urticating fikments of the Eolidæ. Q. J. M. S. (Microscop. Journ.), v, 3. 